\title{
Headache as a single clinical manifestation of a colloid cyst in the third ventricle
}

\author{
Cefaleia como manifestação clínica única de um cisto coloide do terceiro ventrículo
}

Marcelo Moraes Valença ${ }^{1}$, Helysânia Shádylla Santos de Farias ${ }^{1}$, Laryssa Crystinne Azevedo Almeida ${ }^{\text {, }}$ Cassia Luana dos Santos França', Karolyne Ernesto Luiz Nobre², Marcelo Andrade Valença', Mário Luciano de Mélo Silva Júnior ${ }^{1}$ Luciana Patrízia Alves de Andrade Valença ${ }^{1}$

'Neurosurgery and Neurology Unit, Federal University of Pernambuco, Recife, Pernambuco, Brazil ${ }^{2}$ FCM, Campina Grande, Paraíba, Brazil

\begin{abstract}
Valença MM, Farias HSS, Almeida LCA, França CLS, Nobre K, Valença MA, Silva Júnior MLM, Valença LPAA. Headache as a single clinical manifestation of a colloid cyst in the third ventricle. Headache Medicine. 2017;8(1):25
\end{abstract}

\section{INTRODUCTION}

The colloid cyst of the third ventricle is a rare tumor. Its estimated incidence is 3 cases per million inhabitants per year. ${ }^{(1)}$ With the more frequent use of neuroimaging, many of the colloid cysts of the third ventricle are incidental findings, so they are asymptomatic lesions.(1)

In a large series of 163 cases, only $40 \%$ of the individuals with colloid cyst of the third ventricle were symptomatic.

\section{CASE REPORT}

In this article, the authors wish to show the images (Figure 1) obtained by MR of a 32-year-old woman complaining of one week of a history of severe, pulsatile, holocranial and continuous headache, partially alleviated with analgesics. There was a progressive increase in pain intensity until a week later when she had a very severe headache, referred to as the worst she experienced in her life, associated with visual impairment, nausea, photo- and phonophobia. Vomiting was not present and she had no previous history of primary headache.

This type of headache associated with colloid cyst of the third ventricle should be valued because the cyst may obstruct the foramen of Monro, causing obstruction in the CSF passage, leading to acute hydrocephalus and sudden death. ${ }^{(1,2)}$

\section{REFERENCE}

1. Beaumont TL, Limbrick DD Jr, Rich KM, Wippold FJ 2nd, Dacey RG Jr. Natural history of colloid cysts of the third ventricle. J Neurosurg. 2016 Dec;125(6):1420-1430. Epub 2016 Mar 11.

2. Spears RC. Colloid cyst headache. Curr Pain Headache Rep. 2004 Aug;8(4):297-300.

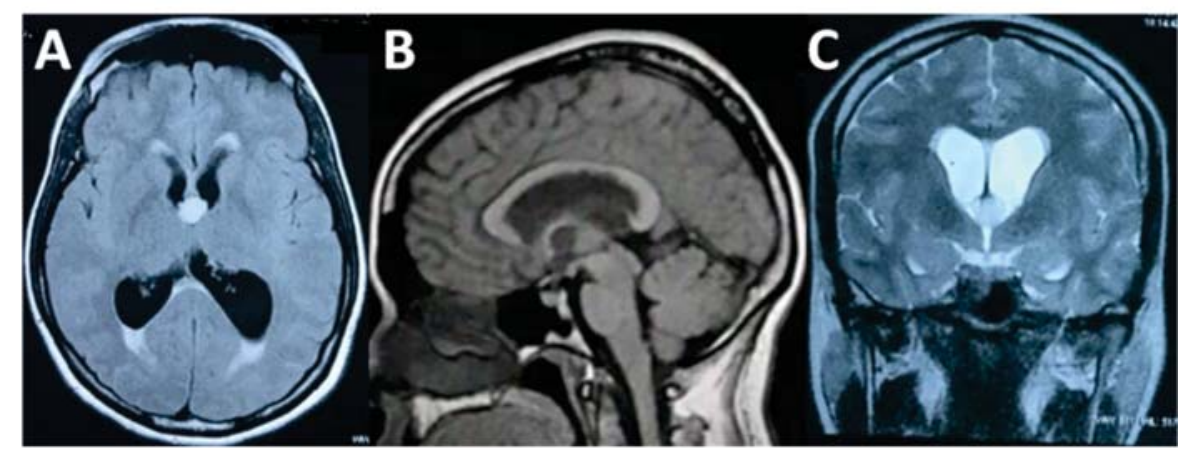

Figure 1. Images obtained by magnetic resonance of the encephalon in the transverse, sagittal and coronal sections. 